\title{
The Study of Effects of Iraq's New Political Geography on the National Security of the Islamic Republic of Iran
}

\section{Based on Lee Norji Martin's theory}

\author{
Akbar Ghafoori ${ }^{1}$ \\ ${ }^{1}$ Department of Political Science, Yazd University, Iran \\ Correspondence: Akbar Ghafoori, Department of Political Science, Yazd University, Iran.
}

Received: May 15, 2016 Accepted: June 2, 2016 Online Published: June 29, 2016

doi:10.5539/jpl.v9n5p230 URL: http://dx.doi.org/10.5539/jpl.v9n5p230

\begin{abstract}
Given that the geography of modern times was one of the most important factors affecting the relations between Iran and Iraq, in this article we have tried to examine the influence of Iraq's new political geography variable factors on the national security of the Islamic Republic of Iran. For this purpose, regardless of the security implications of Iraq's geopolitical constant factors, with placing three variable factors in the political geography means population, natural resources and socio-political institutions in the form of five security variables for Lee Norji. Martin, meaning the political legitimacy, civil rights and ethnic and minorities, military strength, the strength of economic management and natural resources, fifteen areas will be formed (in the annexes, these fifteen areas are in the table). The question that arises here is that what is the impact of Iraq's new political geography on the national security of Iran? The hypothesis that we are looking to review it is that changes in some areas of geopolitical of Iraq, after the United States invaded Iraq, made threats to the national security of Iran. The main objective of this paper is to study Iranian security changes in the first ten areas and to present solutions. Since the Iraq has not achieved stability yet, next five areas need further research and in this article do not occur.
\end{abstract}

Keywords: geopolitics, national security, political legitimacy, authority, sovereignty, political and social institutions, ethnic and minority rights

\section{Introduction}

Geography undoubtedly is one of, and maybe the most important factor affecting the interaction between Iran and Iraq. Even before the Iraq, the geographic factors affected the political sectors behavior of Iran and the Ottoman Empire. After the invasion of United States of America and fall of Saddam in 2003, wide changes happened in this country and in the interaction between politics and geography; Iraq's environment was not affectless from these changes. It seems that changes in the political geography of Iraq had and have implications for the national security of Iran.

This article addresses two fundamental concepts of geopolitics and security and interaction these two cases between Iran and Iraq. Geopolitics has old roots. Scholars have long recognized the relation between geography and politics and have aware of its importance. For example, in the ideas of Aristotle, Ibn Khaldun, Jan bden, Montesquieu and... a trace of geopolitics can be found. However, a person who effectively had an effect on other geographers' thinking, so also is known, as the father of geopolitics is the Friedrich Ratzel. His influence on the House Hofer, theoretician of Nazi Germany, is undeniable.

Political geography and Geo-politic terms are usually used interchangeably. Despite the differences that exist between them and the former emphasizes the impact of policies on the environment, and the latter emphasizes on the impact of the environment on the policy, But both are interaction between geography and politics. Political geography is primarily engaged in spatial analysis of the political phenomena and considers the spatial symbols of the political process. (Beatrice Zhylbn and Aula Coast, 2008, 12)

In determining the effective factors in the political geography, two categories of fixed and variable factors are named. In fact, the fixed factors are actually the same natural and geographical phenomena. (Garfinkle, 2007,11) which can be named in the example of it, geographical location, space and its division, the extent of soil, 
topography and the countries' shape. Variable factors, which may some of them also have natural origins, because of the quantity role in them, they are considered as variable factors and three factors: population, natural resources, and political and social institutions can be named. (Ibid, 76). The focus of this article is based on varied factors.

On the other hand, the security is a multifaceted concept that is the incorporation of a strong emotional and political appeal with a wide variety of key meanings. Such fusion and combination represents the accumulation of meaning and an unusual capacity lies in this concept. (Asgari, 2002, 50). The concepts of security at three global, regional and national levels are considered. In this paper, the approach of Lee Norji Martin is used that is rejected a realistic approach because of not being prevented and is posed the third approach (Martin, 2004, 37-33). In his approach, national security is the ability of a government to exercise or prevent threats to three components: a) acts of intimidation or prevention of threat to territorial integrity; b) acts of intimidation or prevention of threat to the community; c) acts of intimidation or prevention of threat to the regime (ibid., 38).He knows the national security in the Middle East the function of the following five key variables: 1. political legitimacy; 2. Citizen and Social and ethnic minorities' right; 3. military capabilities; 4. the power of economic management; and 5. Having strategic natural resources such as oil, gas and water (Nasri, 2005, 28).

By putting three variable factors of political geography, in the form of Lee Norji Martin' five key variables, fifteen areas will form and with the application of these areas in the political geography of Iraq and national security of Iran, we realize that, just by occurring changes in the area of political geography in Iraq, we witness the transformation in fifteen areas of the security National of Iran.

\section{Theoretical Framework}

What is mentioned in this article as a conceptual framework is a hybrid approach of Lee Martin that knows the national security as a dependent variable, ranging from five independent military capability, political legitimacy, ethnic-religious tolerance, access to natural resources and economic management variables. The major difference of combined approach, compared to other approaches (realist and liberal) is that the current approach considers non-civilian factors as well as military defense that such a thing can introduce national security main essentials (Martin, 2004, 38). Lee Martin knows the national security as the ability of a government to exercise or stop the threat to three components: territorial integrity, community and Regime. Hence, based on the following two cases, it can be said that, a country has more secure or less: (1) the extent of the threats against three elements: land, society and political regime. (2) The ability of the state to apply or avoid the threat to the three elements above (ibid. 38).

The analytical level that Martin pays attention to it in his definition of national security is the government. The government, in international relations in general and in the Middle East, specifically is considered as the main operating unit. In addition, the government is considered the primary focus of policy-making on issues related to national security, so that's why the government is the main objective of national security threats. Based on this level of analysis and definition of national security, as we did for the dependent variable, we define five independent variables that are the main sources of threat causing or the threat debugger in the Middle East, which has a direct impact on national security from Martin's point of view.

\section{Military Capabilities}

Government to deal with external threats and internal threats of armed groups needs military capabilities. Domestic threatening national security groups include terrorists, guerrillas and those who thought the coup and rebellion. No doubt that the government needs economic empowerment for achieving military power and equipping troops. In addition, the necessity to provide fragile natural resources, security forms an important part of defense approach and this matter dictates the amount and types of military capabilities. In addition, foreign and defense policy of a country can increase or reduce its military capabilities. From Martin's point, various Middle Eastern countries increase their military capability due to the following factors:

_Facing difficult problems of political legitimacy

_Religious and ethnic differences

_ Ideological conflicts that hinder the confidence-building measures (ibid., 43).

\section{Political Legitimacy}

A regime that has a high political legitimacy, will have the deterrent capability against the civil war or revolution, such a regime can use the support of the masses, and deals with a variety of economic crises and natural resources poverty. If the masses do not believe in the political legitimacy of the regime and the regime falls in 
the vortex of civil war, its military capability declines and external enemies can take advantage of the civil war and use the internal enemies of the regime to destabilize it or directly intervene in that country (ibid., 44). From the perspective of Martin, what the countries are facing most in the Middle East is a crisis of political legitimacy that has made the Middle East countries to have a kind of fragility in their national security.

\section{Religious and Ethnic Tolerance}

Ethnic and religious conflicts have threatened the security components of territorial integrity, community and even the legitimacy of the regime. Extremist groups in the Middle East have led and guided the violence not only against the government but also against religious minorities. In general, societies that have a homogeneous structure have more resistance against social fragmentation, because they are relatively coherent in terms of ethnic and religious.

Ethnic and religious differences are capable of making the country vulnerable against foreign intervention, as well as the density of ethnic groups, in areas where have vital natural resources the country, can be dangerous because it is possible that the ethnic groups with sabotage and explosions affect adversely on the economic empowerment of the country. In the eyes of Martin, countries where the religious or ethnic groups have tolerance and necessary toleration can live together in peaceful coexistence and put the national security into a serious challenge (ibid. 45).

\section{Economic Empowerment}

Each government to increase its legitimacy should provide a minimum economic welfare of the society, and this is obvious and necessary for the durability of the regime and society. In this context, the government may monitor the economic market or acquire full control of production and distributive facilities. The more government agencies involved in the economy or the allocation of economic benefits, the more needs for economic empowerment is.

A weak economy prevents the government supports the military industries and national facilities or purchase military equipment from abroad. Moreover, the economic weakness undermines the government power in ensuring social welfare and unemployed employment. These issues have consequences for the political system and increase the threats against the legitimacy of the regime; these threats, particularly in areas where ethnic and religious groups together are economically apart, are more tangible.

\section{Access to Vital Natural Resources}

The economic empowerment of a country with natural resources such as energy, food and water that are vital for the survival of people's lives has a strong connection. Essentially, the definition of a country territory is related to this important fact that, which natural resources are within the country, to support the national economy and which of them should be procured from abroad; the geographical region and climatic conditions will affect the principle of having economic resources. As mentioned above, if a country has a strong economy, it could provide the shortage of resources from other countries, on the other hand, natural resources play an important role in strengthening the country's economy (ibid. 47).

So in general, it must be said that, if the validity of a hybrid approach (which in this article is studied) will be proved, it can be tested as a paradigm of a government, and then used for national security analysis of other governments and the Middle East, also by the application of this model in different countries, we can see how the governments show different reactions against the same problems and in specific time. Finally, this hybrid approach that maintains establishing a paradigm for the study of national security should be tested in all regions of the world. Therefore, in order to use the combined approach to explain the national security of the Middle East in this study, we investigate the impact of Iraq's political geography on Iran's national security.

\section{Iraqi Population}

The simplest form of studying the population of countries from the viewpoint of geopolitics is their geographic distributive of them. Obviously, in analyzing the population, we should not consider only quantitative aspects because the most important geopolitical factor is human. In terms of geopolitics, a creative and thoughtful man who has highly subjective and objective skills and can avoid the incidence of adverse events in the future with prediction, is considered. (Ezzati, 1992, 91).

1) Iraq's population and the political legitimacy of Iran: Iraq has a diverse population. More than $75 \%$ of the populations are Arab. Other races include 19\% Kurds, Turkmen and Assyrians, and other denominations, such as the Sabeans, Yazidis and..., that involve about 5 percent. 97\% of the populations are Muslim, of which 60 to 65 percent are Shia and 32 to 37 percent are Sunni. (Mozaffari, 2008, 34). (To see the distributive of Iraq's population rack. Maps 1 and 2). 
Iran political legitimacy tied to the Iraqi population in two serious fields. According to the former statics and regardless of 97 percent of Iraq's population being Muslim, between 80 to 85 percent of Iraq's population are Shia and Kurds. Serious political and psychological ties between the Kurds of Iran and Iraq as well as Shiite interactions of Iraq and Iran of existing holy sites in Iraq, the seriousness of this component made the interaction between political geography of Iraq and national security of Iran very seriously.

In explaining the political legitimacy at three levels of individual, political system and the country, three aspects can be traced: the authority is formed from balance of power and respect for the individual level, legitimacy is formed in the political system, and at the country level, the governance is formed (cf. Figure 1) (Alem, 2004,34). Iran's political legitimacy affected of the Iraqi population in the political system, the country and, to a lesser extent, the individual is subjected to change.

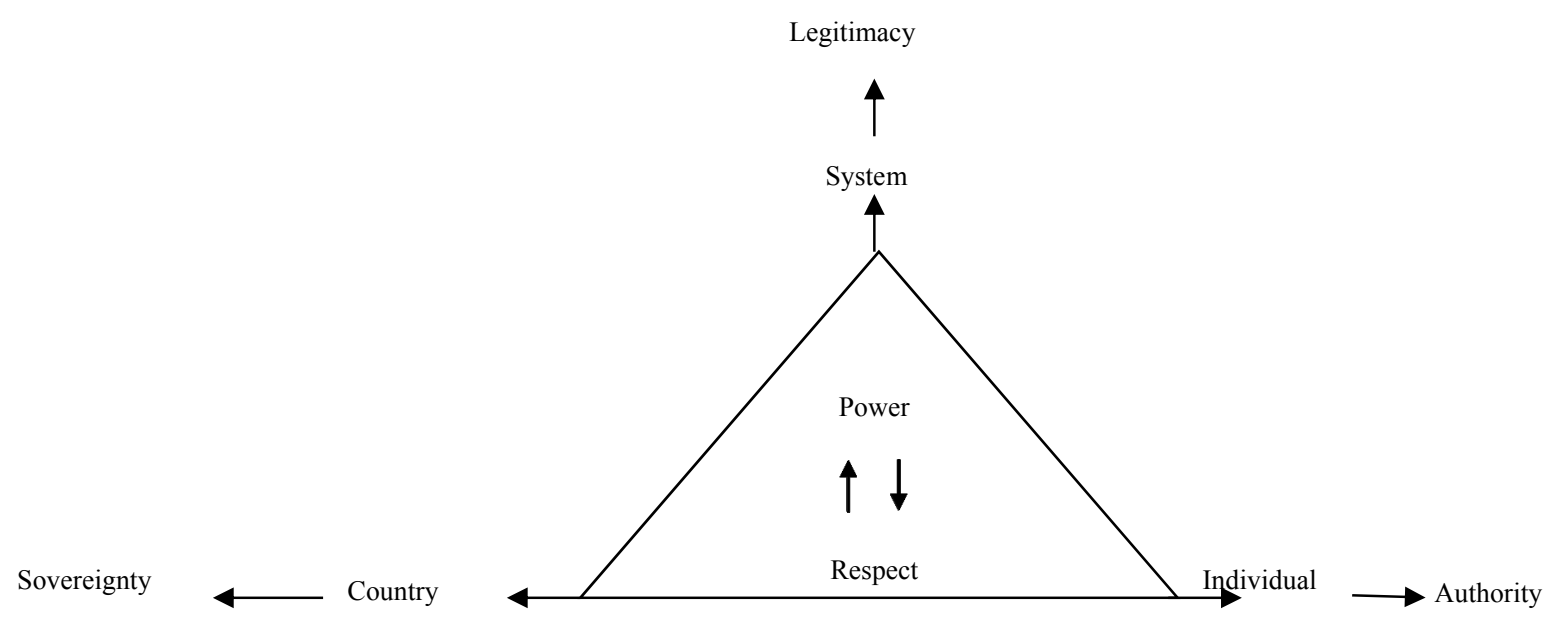

Figure 1. The relation between power and respect for the individual, government and country levels

For an explanation of the incident changes, it is necessary to distinguish between the two categories of the system (Islamic Republic) and the country (Iran). It seems that political legitimacy in the system's field and as a result, Iran's national security is exposed to the threats and opportunities:

A) The fifty-sixth principle of the Islamic Republic constitution ... the constitution is considered two divine and human base for the Principle of sovereignty (Hashemi 1993, 13). Apart from the human basis, the divine basis of sovereignty in the constitution is summarized in the principle of velayat-e faqih. With Shiite power in Iraq, the re-introduction of Najaf's Theological Seminary against Qom as the constitutive principle of velayat-e faqih and, probably, a Shiite transfer centrality from Qom to Najaf, it seems that the principle of velayat-e faqih and consequently political system is seriously exposed to threatening. In other words, despite the fact that The Dawa Party Supreme Council, and the Iraqi Islamic Party is formed main religious Shiite groups in Iraq- they had a long-standing presence in Iran and had close ties with the leaders of neighboring countries, they have always insisted on the fact that they do not want to install an Islamic system based on the ruling pattern in Iran from the beginning of a political system change in Iraq (group of authors, 2008, 200). Because, as we know, after the victory of the Islamic Revolution, what is the main priority for the Islamic Republic's leaders was promoting and exporting his revolution, which is essentially the same as promoting the principle of velayat-e faqih, as the influence theory, in jurisprudence Shiite, throughout the Muslim world and providing a new model of religious government. Lack of Iraqi Shiite leaders to establish a theocracy in this country can be considered a threat from the view of the Iranian leaders could not achieve their goals. In addition, the authority of Shiite authority and competition between Najaf and Qom theological Seminary for leadership and authority in the hands of the Shia world can be considered important in the relations between the two countries, especially from Iran, which is ruled by ideological system. This topic is a serious threat, since a Shiite government was in Iraq, and the look that they and especially, Shiite references of seminary in Najaf have with the government of Shiite jurisprudence, causes that in case of Iraqi government's success, the neighboring countries' models the Iraqi governing model and this issue has made the Islamic Republic a political Islam fan that has an ideology of universality, put in isolation. Consequently, in the isolation of Iran, it can have serious consequences on the national security of this country. 
B) The second threat to the regime is the Kurds' power in Iraq and the possibility of modeling and influence of Iranian Kurds for them and requesting the same rights of the Iranian political system. However, these demands face serious obstacles, according to the constitution of the Islamic Republic. Because, according to the Iraqi constitution that was adopted in 2005, rights such as autonomy and Kurdish official language alongside Arabic language is recognized (Ahmadi-Pour et al., 2007, 129), while in the Iranian constitution, these rights were not included for Kurds.

C) The third threat arises from the possibility following the Iranian Shiites of Iraq's Shiites. Carriers of Shiite thought, now, are the most important player of power in Iraq in a modern manner and in accordance with international norms, but this time, emerging legitimacy is arising from the election and freely and no particular religious to select and be elected is not included (Nasri, 2005, 83). However, this is impossible in accordance with the constitution of the Islamic Republic of Iran. Since the wave of democratization and the establishment of secular governments are widespread in the region, forming another secular government in neighboring Iran would lead to greater Iranian influence from this government due to its more efficient.

D) Perceived opportunity for Iran's political system is the better and more likely interaction of Iraq and Iran, because of the power of Shiites in Iraq and religious similarity with the Iranian government. This probability was largely a reality, in the short history of the new Iraqi government. In addition, the rise to power of Shiites in Iraq would cause the leaders of this country stop nationalist and Arab radical ideas and have less claim to the leadership of the Arab world. Fading Pan-Arabists trends and religious ties importance between the two countries could play an important in reducing tensions and finding solutions on common issues (Tishe Yar and Zahiri Nejad, 2005, 139). On the other hand, the power of Shiites in Iraq, can take the opportunity for Iran to take steps in the direction of strategizing the Shiites role in power and political development in the region and through stabilizing and strengthening the role and status of Iran, in the competition fields in the Middle East and the Persian Gulf region. The Arab world's concern from the formation of the "Shiite Crescent" or Shiite geopolitics, which was first proposed by King Abdullah of Jordan, placed in the mold. (Fuller, 2005, 55).

At the country level, a threat and an opportunity are imagined. The threat comes from Iranian Kurds. Iraqi Kurds, in the new government have reached big points like a) current Iraq an "independent and sovereign country that its government systems are democratic and federal parliamentary republic"1, b) "Arabic and Kurdish are the official languages of Iraq ... "2. Considering that the population of Iranian Kurds to the rest of Iranians is less than the Kurdish population of Iraq to the Iraqis, the accessing possibility to above rights is hard in Iran for the Kurdish. As a result, it seems that the Iranian Kurds' trend has increased to the cross the border and the borders of Iran will be exposed to threaten and by threatening territorial boundaries, the Iranian government would be at risk. This is especially serious when we consider the recent whispers for dividing Iraq into three regions of Shiites, Sunnis and Kurds.

On the contrary, it seems that the new Iraqi political geography in southern Iran will create opportunities for Iran. Throughout recent history, divergence tendencies in Khuzestan region and especially among Iranian Arabs are seriously shown itself (Sariol Ghalam, 2002, 15). After the demographic changes taking place in Iraq and the loss of power in the country's Sunni Arabs, it seems that the divergence threats of Iranian Arabs are eliminated, or at least neutralized.

What should be noted at the individual level are damages that may be concerned with the authority of the Iranian leadership. In case of defining the system legitimacy, based on personal aspect and failure to institutionalize it and according to the advertisement and positive atmosphere of Ayatollah Sistani, in this level, the political legitimacy would be threatened.

2) Iraq's population, and civil rights and collective ethnic groups and minorities, in Iran: perceived threats in this area are partly mentioned in the previous section, but achieving an important minority in Iraq- which means Kurdish- to high rights such as recognition of two Kurdish and Arabic languages in the country, the Kurdish President (Jalal Talabani) Foreign Minister (Hoshyar Zebari), Minister of industry (Fawzi al-Hariri), Minister of water resources (Latif Mohammed Rashid), Minister of housing (Bayan Dazayi) and the Minister of environment (Narmin Othman), as well as deputy Prime Minister for economic Affairs (Barham Salih) (Hagh Panah, A 2008, 101) and..., can have the expression of these desires on the part of Iranian Kurds and in case of atherosclerosis against these wishes, it becomes a serious security threat. But it seems that, the participation of Iraqi Kurds in the political structure of the country, will reduce the possibility of serious coalition formation among the Iraqi Kurds with Iranian Kurds, because attempts to establish a Kurdish state, with its heterogeneous composition, cultural

\footnotetext{
${ }^{1}$ Rack. Article one permanent Iraqi constitution.

${ }^{2}$ Rack. Article four permanent Iraqi constitution.
} 
differences and political differences between the Kurdish parties in different countries in the region, had no attraction for the Kurds of Iraq. Social welfare, the political security and economic wealth, all three can be achievable within the framework of the new rules in the new Iraq for the Kurds in this country. Thus, the theory of "rational choice" that is used for explaining the reasons for the emergence of ethnic movements, here from another perspective, can justify new approaches of an ethnic minority, compared to a newly developed order (Hagh Panah, b 2002 73). As a result, this lack of willingness by the Iraqi Kurds to the Kurds of Iran reduces the amount of these threats.

3) Iraqi population and military capability of Iran: although with advances in technology, human importance as an element of military capability has declined, but it is still one serious factor. From Martin's point of view, the government needs military capabilities in order to deal with external threats and internal threats of armed groups. In his view, the internal desire of the population to mobilize and employee's commitment to sacrifice for the sake of the state, society and homeland has a privileged position in providing security. The amount of this interest to the nation and the homeland depends on the legitimacy, coexistence, and tolerance of ethnic-religious in the country (Martin, 2004, 43).

The incident that happened after the fall of Saddam Hussein in Iraq is turning a government lacks a public base and replacing it with a government that has a high talent in achieving public support and ethnic and minorities (Haji-Yousefi and Soltaninejad 2007, 126). In this area, if Iran and Iraq enter into a zero-sum game, the people of Iraq's military capabilities and relying can be a threat to national security of Iran. This threat will be serious when we consider America's military presence and its allies in Iraq too. Because it seems that, with the approach of the new Iraqi government to the Western countries and issuing establishment military and America's information base license, in parts of its territory, especially in Kurdistan regions and Iranian borders adjacent, influence the future bilateral relations and have an impact on national security of Iran.

According to the logic of geopolitics, as Aspravt says factors and geographic variables of Iraq have effects the two types of expansion policies: First, the actual and environmental conditions of Iraq; second, the perception of the country's leaders from geographical conditions and location. Therefore, to understand the expansion geographic factors of Iraq, we should consider both the operational and psychological variables (Dehghani, 2003, 56). From the operational and psychological variables above, the first one is defined as a geography fixed element and the latter is defined as a variable element. In feasibility, it can be said, given the choice of the political elite in Iraq, the country's top political underdevelopment, and lack of mental stability of public, there is the possibility of the emergence of elites, that do not agree with the current atmosphere of tolerance among the elite of Iraq. (Haji-Yousefi and Soltaninejad, 2007, 74).

In this case and given the constant geopolitical motives and the unity of Iraq with West, a serious threat arises for the national security of Iran. On the other hand, and given Iran's considerable superiority in the field of fixed geopolitical factors and Iran's and demographic superiority in terms of qualitative and quantitative, these threats would be weakened somewhat.

4) Iraq's population and economic leadership power of Iran: in this area, also the economic rights of the Iraqi Kurds are considered. Iraqi Kurds in the autonomous region of Iraqi Kurdistan are under the leadership of Serok (leader) Barzani have the increasing economic rights. Martin stresses that every government should provide a community minimum economic welfare for increasing its legitimacy (Martin, 2004, 46). With the negligible extent, it can be accepted that the Islamic Republic has provided this minimum prosperity for its community, but what the Kurds in Iraq had, is something much more than the minimum. Iraqi Kurds in three provinces of Dohuk, Erbil and Sulaymaniyah have a three-drawer cabinet ministers led by Prime Minister Nechirvan Barzani and economically separated from the central government. In addition, $17 \%$ of central government funds will be spent on Kurdistan (Hagh Panah, a 2008, 95).

This makes benchmarking Iranian Kurds and the Iraqi Kurds may want the same rights from Iran Government. A discontent and even asking for autonomy of these areas will accompany because of poor economic management in Iran and failure to allocate a significant budget to the Kurdish areas. On the other hand, this could be a model for the Arab and Turk minorities of Iran in economic autonomy.

5) The population of Iraq and having Iran the strategic natural resources, such as oil, gas and water: It seems, in this part, the Iraqi population has no effect on Iran's strategic resources and in the field of national security has not relevance.

\section{Iraq's Natural Resources}

Actual and real value of any country depends on the frequency and quality of its resources. The economic 
empowerment of a country has a strong connection with natural resources, such as energy, food and water that are vital for the survival of people's lives. Essentially, the territory of a country definition is concerned to the matter that, which resources are located in the country to support the national economy and which of them should be provided from abroad. There are also some sensitive natural resources, on the border of neighboring countries, can help to create or deepen the crisis, as a country may have a position to cut off that source (Jafari Waldani, 2003, 105). The wealth of a country depends on its utilization of resources and its own products. It is possible; a country has a large number of wealth resources, without being able to use it properly. Natural resources are divided into two groups: a) food sources; b) mineral resources (Ezzati, 1992, 95-94). Despite the importance of food sources and changes occurring in it and its relation to Iran's national security, we in this discussion, will consider further mineral resources. For this purpose, first, we review, a comparison of Iran and Iraq resources through statistical tables:

Table 1. Oil proved reserves (thousand million barrels)

\begin{tabular}{|c|c|c|c|c|c|c|c|}
\hline $\begin{array}{l}\text { The reserves amount } \\
\text { of acountry }\end{array}$ & $\begin{array}{l}\text { At the end } \\
\text { of } 1985\end{array}$ & $\begin{array}{l}\text { At the end } \\
\text { of } 1995\end{array}$ & $\begin{array}{l}\text { At the end } \\
\text { of } 2004\end{array}$ & $\begin{array}{l}\text { At the end } \\
\text { of } 2005\end{array}$ & $\begin{array}{l}\text { At the end } \\
\text { of } 2006\end{array}$ & $\begin{array}{l}\text { At the end } \\
\text { of } 2007\end{array}$ & $\begin{array}{l}\text { The overall share } \\
\text { in the world }\end{array}$ \\
\hline Iran & 59.0 & 93.7 & 132.7 & 137.5 & 138.4 & 138.4 & $11.2 \%$ \\
\hline Iraq & 65.0 & 100.0 & 115.0 & 115.0 & 115.0 & 115.0 & $9.3 \%$ \\
\hline
\end{tabular}

Resource: http://www.bp.com.BP statistical review of world energy 2008

Table 2. Daily oil production (thousand barrels)

\begin{tabular}{llllllll}
\hline The country's & 2003 & 2004 & 2005 & 2006 & 2007 & $\begin{array}{l}\text { The rate of production change } 2007 \text { to } \\
\text { production }\end{array}$ \\
\hline Iran & 3999 & 4081 & 4049 & 4388 & 4401 & $0.4 \%$ & $5.4 \%$ \\
Iraq & 1339 & 2010 & 1820 & 1999 & 2145 & $7.3 \%$ & $2.7 \%$ \\
\hline
\end{tabular}

Resource: http://www.bp.com.BP statistical review of world energy 2008

Table 3. Daily consumption of oil in the Middle East (thousand barrels)*

\begin{tabular}{llllllll}
\hline The country's consumption & 2003 & 2004 & 2005 & 2006 & 2007 & $\begin{array}{l}\text { The rate of change 2007 to } \\
2006\end{array}$ & $\begin{array}{l}\text { The overall share in the } \\
\text { world }\end{array}$ \\
\hline Iran & 1513 & 1575 & 1659 & 1625 & 1631 & $0.4 \%$ & $1.9 \%$ \\
Kuwait & 238 & 266 & 280 & 275 & 276 & $0.3 \%$ & $0.4 \%$ \\
Qatar & 77 & 84 & 98 & 79 & 95 & $21.7 \%$ & $0.1 \%$ \\
Arabia & 1684 & 1805 & 1891 & 2005 & 2154 & $7.2 \%$ & $2.5 \%$ \\
Emirates & 333 & 355 & 376 & 376 & 419 & $7.7 \%$ & $0.6 \%$ \\
The rest of the Middle East & 1423 & 1467 & 1519 & 1546 & 1608 & $4.0 \%$ & $1.9 \%$ \\
\hline
\end{tabular}

* In this table, the consumption of Iraq is very low and along with low consumption countries of Middle East, they only have 1.9 per cent of the world's total consumption.

Resource: http://www.bp.com.BP statistical review of world energy 2008

Table 4. Proven gas reserves (trillion cubic meters)*

\begin{tabular}{lllllll}
\hline $\begin{array}{l}\text { The resource amount of a } \\
\text { country }\end{array}$ & $\begin{array}{l}\text { At the end of } \\
1985\end{array}$ & $\begin{array}{l}\text { At the end of } \\
1995\end{array}$ & $\begin{array}{l}\text { At the end of } \\
2004\end{array}$ & $\begin{array}{l}\text { At the end of } \\
2005\end{array}$ & 2006 & 2007 \\
\hline Iran & 13.99 & 19.35 & 26.74 & 26.74 & 27.58 & 27.80 \\
Iraq & 0.82 & 3.39 & 3.17 & 3.17 & 3.17 & 3.17 \\
\hline
\end{tabular}

*Iraq does not have a significant role in the production and consumption of gas.

Resource: http://www.bp.com.BP statistical review of world energy 2008 
Table 5. Production rate and consumption of Iranian gas per year (billion cubic meter)

\begin{tabular}{lrrrrrrrl}
\hline $\begin{array}{l}\text { The rate of index in the } \\
\text { year }\end{array}$ & 2003 & 2005 & 2006 & 2007 & $\begin{array}{l}\text { The rate of change compared to } \\
2006\end{array}$ & $\begin{array}{l}\text { The overall share in the } \\
\text { world }\end{array}$ \\
Production & 81.5 & 84.9 & 87.5 & 108.6 & 111.9 & $3.0 \%$ & $3.8 \%$ \\
Consumption & 82.9 & 86.5 & 88.5 & 108.7 & 111.8 & $2.9 \%$ & $3.8 \%$ \\
\hline
\end{tabular}

Resource: http://www.bp.com.BP statistical review of world energy 2008

Now, according to the above statistics, we are studying Iran's national security in quintuple variables of Martin:

1) Iraq's natural resources and political legitimacy of Iran: after the collapse of Saddam's regime and Iraq lifting sanctions, as we see in Table 2, a tremendous growth took place in oil production in Iraq. This is while, in the 1990s, Iraq's oil production has been less than a million barrels per day, and only after 2000, we witnessed the growth in Iraq's oil production and its exchange with the Food and Drug. (Mandil, 2003,3) If we put the Iraq's oil production growth along with negligible consumption in this country - according to table 3- we see that the major part of the country's oil production is exported and even in 2004, 2005, 2006 and 2007 , they have surpassed of Iran's oil exports. If increased consumption in Iran has rising growth as now (see. Table 3) According to the three times population of Iran and in case of stability in Iraq and the country's sound economic management, in the coming years, we will see the well-being of citizens in this country compared with Iranian. Due to the extensive exchanges between citizens of these two countries, that primarily was for pilgrims traveling of the two countries to pilgrimage sites, comparing the Iraqis situation from the Iranians side could have a negative impact on Iran's national security.

2) Iraq's natural resources, and civil rights and collective ethnic groups and minorities in Iran: Although, oil resources in Iraqi Kurdistan are small, but that low rate is dominated by the Kurdistan Regional Government and is spent on it. This can have a negative psychological impact and publicity on the Kurds of Kermanshah region and the Arabs of Khuzestan, and they demand the same rights as Iraqi Kurds from the Islamic Republic government.

3) Iraq's natural resources and military capabilities of Iran: during Saddam's era, about a third of the population of the country were involved in military issues with relying on natural resources (Tisheh Yar and Zahir Nejad, 2005,131), which this matter provides growing military capabilities in Iraq. Now, according to the current government coalition with the West and its wide oil exports, a bright military future can be seen in the Iraqi's army. This is while, due to the facing sanctions and lack of proper investment in the petroleum resources, Iran is facing serious problems in the development of its military capabilities. However, we should not ignore Iran's nuclear industry opportunities, which can even cause a jump in the military capabilities and Iraq does not have it.

4) Iraq's natural resources and Iran's power of economic management: A look at Table 1, we see Iran's potential power in terms of natural resources for economic development. However, we cannot ignore the Iraqi's per capita excellence in the resources; however, the main issue is poor economic management that especially will be more serious with Iran's oil production at a slower pace than consumption. If we put this issue along with a favorable image of the current Iraqi government, and not-so-favorable image of the Iranian government, probably an economic crisis, resulting in a security crisis is ahead of Iran. This area forms one of the most important threats to national security of Iran.

5) Iraq natural resources and Iran having strategic natural resources of oil, gas, and water: in this area, the important matter of Arvand River is showing off as a crucial waterway in Iraq. During the recent Iranian history, there has always been conflict over this issue and in some cases, the treaties are signed, that most notably of them was the 1975 Algiers Accord between the king and the government representative Hassan al-Bakr (Saddam Hussein). The most important article of this treaty is determining Thalweg line as the border between the two countries. (Jafari Waldani, 2003, 154). According to the historical record, and failure to secure the full peace treaty between Iran and Iraq since the eight-year war, we cannot completely deny the hardware encountering probability in the future. Due to the good relationship between Se Roque Barzani with Israel, after the fall of Saddam, the possibility of using the Shah's trick, against Hassan al-Bakr, for imposing a contract in 1975meaning the support of Iraqi Kurds against the central government of this country, in collaboration with Israel-by the Iraqis against Iran, is not far-fetched. If this happens, we should wait for huge disaster for Iran's national security. On the other hand, considering that the most important source of income for Iraq is the country's crude oil sales, to convey this substance to international markets, there are many problems facing Iraq. In fact, Iraq 
little access to the open sea and placing the most important exporting oil ports of this country on the fringe of the borders of Iran, and joint ownership of the two countries on the Arvand River has caused this country's security free access to transferring oil tankers of Iraqi crude oil depending on the bilateral relations with Iran. (Tisheh Yar and Zahir Nejad, 2005,136). Thus, if the two countries have entered a zero-sum game, Iran can use this issue as a bargaining chip.

\section{Social and Political Institutions of Iraq}

After the fall of Saddam, a revolution is about to begin in the field of political and social institutions in Iraq. After this event, the Baath dictatorship gave way its position in the system so-called democratic federal that is based on one of the most advanced constitutions in the world. If this system will be successful, Western countries led by America can put Iraq as a democratic tower in the area and put pressure on other countries in the region. In the meantime, it is obvious that the Islamic Republic of Iran will not be safe of the pressure from the West on the one hand, and the Iranian people on the other hand and may bring serious security implications. However, yet the situation of political and social institutions in Iraq is not clear, according to the country's instability, a clear feasibility study of the implications for Iran's security cannot be possible. This matter and the fact that to what extent the state-building process in Iraq will be successful is a serious problem that can be examined in a separate study (Ibid. 137).

\section{Conclusions}

In this work, it was trying to study the new political geographical security effects of Iraq on the national security of the Islamic Republic of Iran. To this end, the regional and comprehensive theory of Martin was used. Given the extensive ties between Iraq and Iran since ancient times, and especially the intensification of these relations with the spread of communications technology and the fall of Saddam's regime, it seems that changes in this neighboring country will have implications for Iran. Without exaggeration, it should be noted that recent development in Iraq will have serious effects for the security of Iran. As a result, the Islamic Republic of Iran should always try to have high capability in five areas stressed by Martin. In the first area (political legitimacy), it should be tried to set the power and respect relation at all three levels of individual, political system and the country in such a way that power will be based on respect and not vice versa. In the second area (civil rights and social and ethnic minorities), it should be treated in such a way that, Iranian ethnic groups will be sensitive to the fate of their country and contribute themselves in their country's progress. In three other areas, with a proper planning, the country's natural and human talent and capacities should be used desirably so that to be safe from potential security vulnerability.

\section{References}

Ahmadpur et al. (2007). the impact of government in northern Iraq Aaqlym on Iranian Kurdistan. Journal of Afagh Amniat, (2/3).

Asgari, M. (2002). transformation of discourse and redefinition of the security concept. Defense and Security Studies Quarterly, Spring ninth year.

Asghar, J. W. (2003). Iran's foreign relations (after the Islamic Revolution). Tehran: Avaye Noor Publication.

Beatrice Zhilben, \& Ayolakost. (2008). geopolitical factors and ideas, translated by Ali Frosti. Tehran, Amn publication.

Claude, M. (2005). the geopolitics of Oil after the Iraq War, The geopolitics of Energy: The Asian Shift Aspen Institute Italia.

Fereshteh, M. (2005). new component of strategic culture in Iraq. defense strategy Quarterly, (10).

Fuller, G. (2005). the Arab Shia: forgotten Muslims, translated by Khadijeh Tabrizi and others. publication of the Shia.

Garfinkle, A. (2007). Geopolitics: Middle Eastern Notes and Anticipations. Retrieved from http://www.fpri .org/obis/4702/garfinkle. Geopolitics middleeast.html

Hagh Panah, Jafar A. (2008). Kurds and foreign policy of the Islamic Republic of Iran. Tehran, Tehran Institute of Contemporary Abrar International Studies.

Hagh Panah, Jafar B. (2002). Kurds and future development in Iraq. Tehran: Center for Strategic Studies.

Hashemi, S. M. (1993). the fundamental rights of the Islamic Republic of Iran (Vol. II). Tehran, Shahid Beheshti University.

Jalal, D. (2003). geopolitical logic in Iraqi Foreign Policy: Causes and Consequences. Journal of Middle East 
Studies, (II).

Lah, E. E. (1992). Geopolitics. Samt Publication.

Mahmoud, S. G. (2002). the new Iraq, the new Middle East, new theoretical consequences for Iran. Middle East Studies Quarterly, (4).

Mandana, T. Y., \& Mahnaz, Z. N. (2005). Iraq's foreign policy: Study the political geography role of Iraq in relations with neighboring. Tehran, Zareh Publication.

Martin Lee Nor, J. (2004). The new face of security in the Middle East, the translation of Ghadir Nasri. Tehran: Center for Strategic Studies.

Mohammad, H. Y. A., \& Ahmad, S. (2007). political order in new Iraq. Tehran: Institute for Political and International Studies.

Qadir, N. (2005a). methodological model for the study of the power sociology: the Republic of Iraq case. Defense Strategy, (IX).

Qadir, N. (2005b). oil, the security dilemma in the new Middle East. Journal of defense strategy, (VII).

Rahman, A. A. (2004). Principles of Political Science. Tehran: Ney Publishing.

The group of authors. (2008). emphasized on the Shiite geopolitics of the Persian Gulf. publications of Armed Forces Geographical Organization.

\section{Appendices}

Table 6 . The effect of political geography variable factors of Iraq on the national security parameters of Iran

\begin{tabular}{|c|c|c|}
\hline $\begin{array}{l}\text { The political geography of the } \\
\text { variable factors in Iraq }\end{array}$ & $\begin{array}{l}\text { Security variables desired by } \\
\text { Lee Nor J. Martin }\end{array}$ & National Security of the Islamic Republic of Iran \\
\hline \multirow{5}{*}{ Iraqi population } & Political Legitimacy & Iraq's population and Iranian political legitimacy \\
\hline & $\begin{array}{l}\text { Civil rights and collective } \\
\text { ethnic groups and minorities }\end{array}$ & Iraq's population and civil rights and social and ethnic minorities in Iran \\
\hline & Military Capabilities & Iraqi population and military capabilities \\
\hline & $\begin{array}{l}\text { The power of economic } \\
\text { management }\end{array}$ & Iraq's population and Iranian economic power management \\
\hline & $\begin{array}{l}\text { Strategic natural resources } \\
\text { such as oil, gas and water }\end{array}$ & $\begin{array}{l}\text { The population of Iraq, and Iran having a strategic natural resources such } \\
\text { as oil, gas and water }\end{array}$ \\
\hline \multirow{5}{*}{$\begin{array}{l}\text { Political and social institutions } \\
\text { in Iraq }\end{array}$} & Political Legitimacy & Iraq's political and social institutions and Iranian political legitimacy \\
\hline & $\begin{array}{l}\text { Civil rights and collective } \\
\text { ethnic groups and minorities }\end{array}$ & $\begin{array}{l}\text { Iraq's political and social institutions and collective rights of citizens and } \\
\text { peoples and minorities in Iran }\end{array}$ \\
\hline & Military Capabilities & Political and social institutions in Iraq and Iran's military capabilities \\
\hline & $\begin{array}{l}\text { The power of economic } \\
\text { management }\end{array}$ & $\begin{array}{l}\text { Iraq's political and social institutions and Iranian economic management } \\
\text { authority }\end{array}$ \\
\hline & $\begin{array}{l}\text { Strategic natural resources } \\
\text { such as oil, gas and water }\end{array}$ & $\begin{array}{l}\text { Iraq's political and social institutions and Iran having of strategic natural } \\
\text { resources such as oil, gas and water }\end{array}$ \\
\hline \multirow{5}{*}{ Iraq's natural resources } & Political Legitimacy & Iraq's natural resources and Iranian political legitimacy \\
\hline & $\begin{array}{l}\text { Civil rights and collective } \\
\text { ethnic groups and minorities }\end{array}$ & $\begin{array}{l}\text { Iraq's natural resources and the rights of citizenship and social and ethnic } \\
\text { minorities in Iran }\end{array}$ \\
\hline & Military Capabilities & Iraq's natural resources and Iranian military capabilities \\
\hline & $\begin{array}{l}\text { The power of economic } \\
\text { management }\end{array}$ & Iraq's natural resources and Iranian economic management authority \\
\hline & $\begin{array}{l}\text { Strategic natural resources } \\
\text { such as oil, gas and water }\end{array}$ & $\begin{array}{l}\text { Iraq's natural resources and Iran having strategic natural resources such as } \\
\text { oil, gas and water }\end{array}$ \\
\hline
\end{tabular}




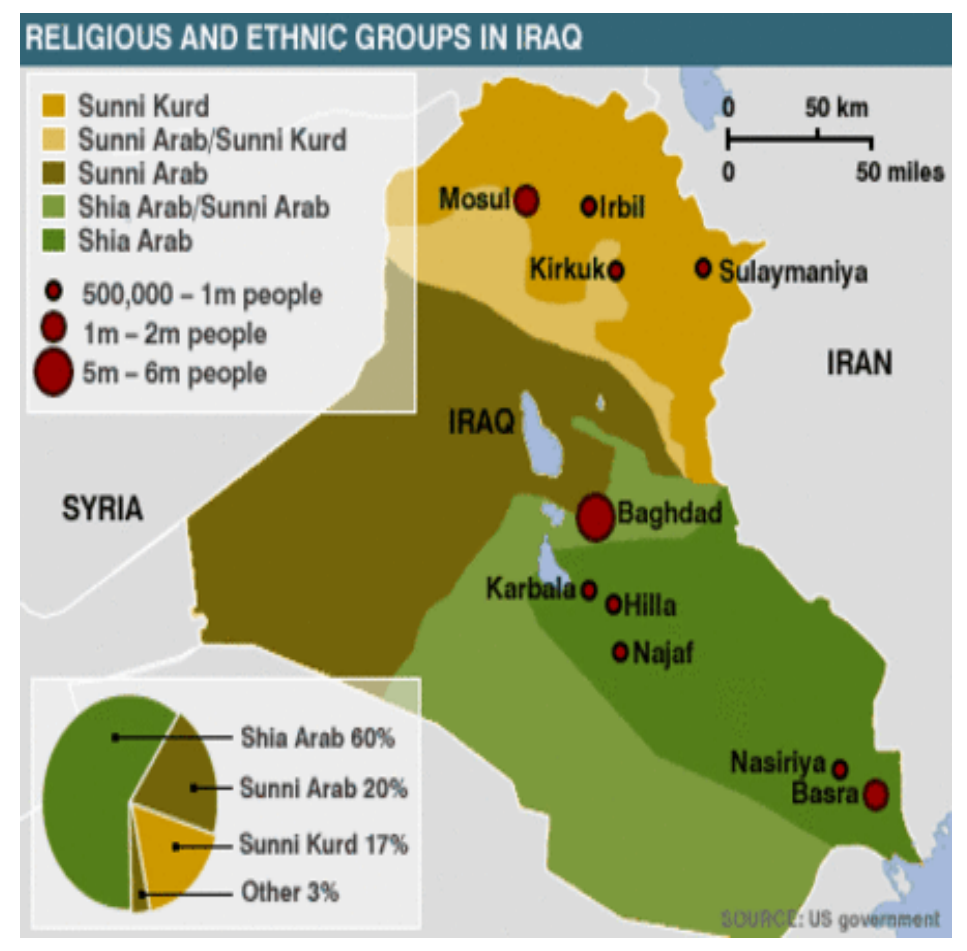

Map 1. Ethnic and religious groups in Iraq 


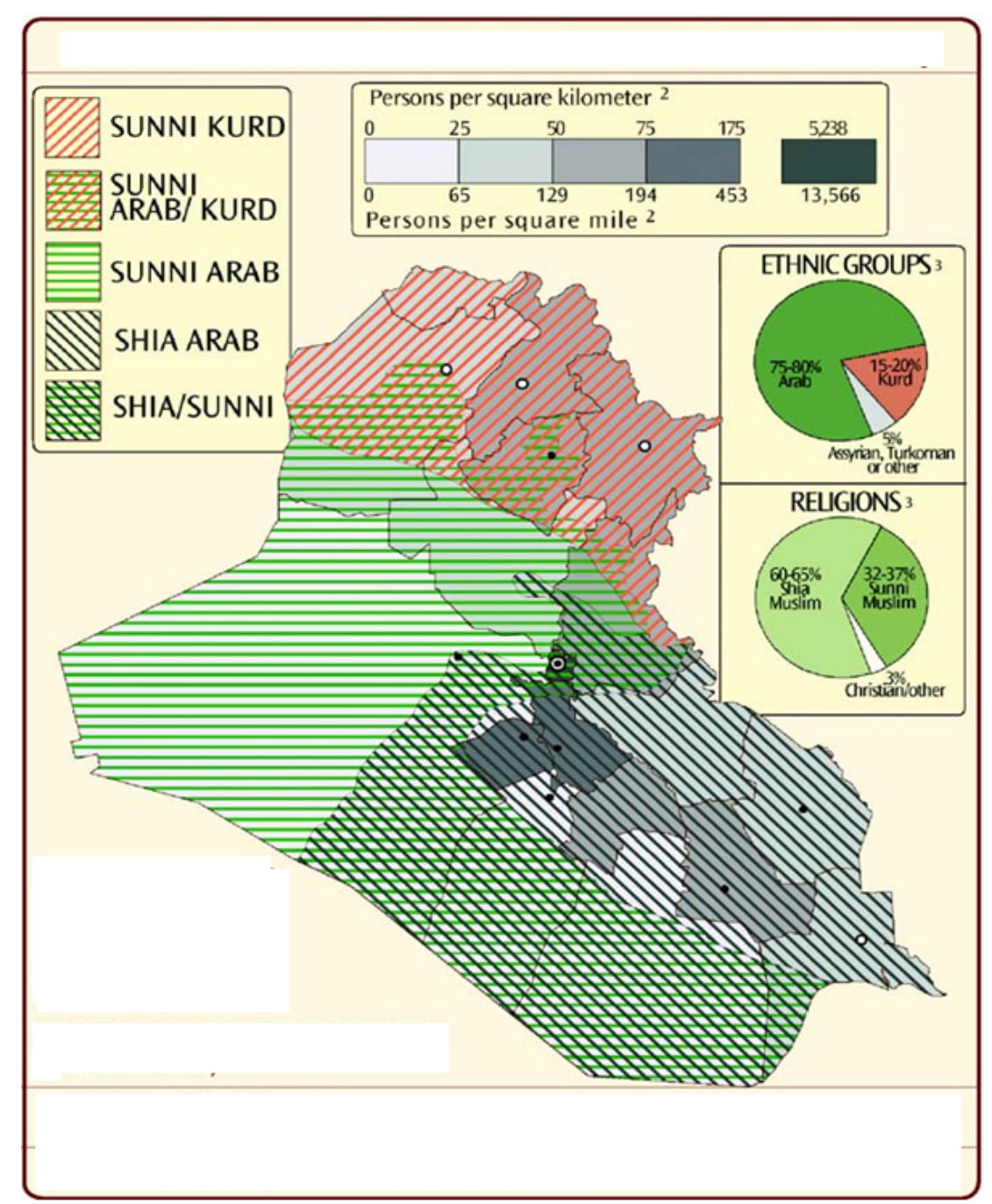

\section{Copyrights}

Copyright for this article is retained by the author(s), with first publication rights granted to the journal.

This is an open-access article distributed under the terms and conditions of the Creative Commons Attribution license (http://creativecommons.org/licenses/by/3.0/). 